\title{
ANTARA DISIPLIN ATAU PENGGEMBALAAN: REKONSTRUKSI AJARAN DISIPLIN GEREJAWI DI GEREJA TORAJA BERDASARKAN REINTERPRETASI TEKS MATIUS 18:15-17
}

\author{
Alpius Pasulu \\ Institut Teologi Gereja Toraja \\ piuzpasulu@gmail.com
}

\begin{abstract}
Abstrak
Artikel ini membangun sebuah model baru teologi disiplin gereja yang didasarkan pada penafsiran ulang atas Matius 18: 15-17. Dalam artikel ini, saya menyimpulkan bahwa sudut pandang dan tindakan yang paling tepat untuk orang berdosa di gereja berdasarkan pada teks Matius 18: 15-17 bukanlah disiplin tetapi untuk memberikan perhatian khusus secara intensif, yaitu penggembalaan khusus. Penggembalaan adalah cerminan kasih Allah bagi dunia yang tidak terbatas dan tak terhingga. Pengampunan harus diberikan terus menerus untuk orang lain karena manusia terbatas dan tidak ada potensi untuk kesempurnaan dan kesucian dalam hidup mereka. Kesempurnaan dan kesucian hidup manusia hanya akan datang di hari-hari terakhir.
\end{abstract}

Kata kunci: Disiplin; gereja; keputusan; pendosa; penggembalaan

\begin{abstract}
This article constructs a new model of the theology of church discipline based on the reinterpretation of Matthew 18:15-17. In this article, I conclude that the most appropriate point of view and action for the sinners in the church based on the text of Matthew 18:15-17 is not discipline but to give special attention intensively, namely special pastoral ministry. Pastoral ministry is the reflection of God's love for the world that is unlimited and infinite. Forgiveness should be given continuously for the others because human beings are limited and there is no potential for perfection and sanctity in their life. Perfection and sanctity of human life will only come in the last days.
\end{abstract}

Keywords: Discipline; church; judgment; sinners; pastoral minsitry

\section{Pendahuluan}

Salah satu ajaran gereja yang bertahan sepanjang masa, khususnya dalam lingkup gereja-gereja "arus utama" adalah Disiplin Gerejawi. Disiplin Gerejawi, selanjutnya disebut Disiplin, telah ada sejak gereja perdana pasca masa Perjanjian Baru. Hal itu terendus dalam kitab Didakhe bahwa Disiplin diberlakukan dan terkait langsung dengan menjaga kesucian hidup, tetapi bentuk dan praktiknya masih sederhana. ${ }^{1}$ Sejak abad ke-6 hingga ke-15 dalam lingkup Gereja Katolik, Disiplin mendapat perhatian yang serius. Perhatian serius itu nyata dengan adanya penyusunan hukum Disiplin secara rinci, dibentuk "aparat", serta disediakan "sarana" untuk mendukung pemberlakuan Disiplin

${ }^{1}$ Aaron Milavec, The Didache: Faith, Hope, \& Life of the Erliest Christian Communities, 50-70 C.E (New York: The Newman Press, 2003): 531. 
secara maksimal. ${ }^{2}$

Pada abad ke-15 dalam lingkup Gereja Katolik Roma (GKR), pemberlakuan hukum Disiplin menjadi sangat ketat dan keras, yang dapat sampai pada praktik hukuman mati. Kala itu dalam GKR, wewenang penentuan hukum Disiplin bagi yang berdosa sepenuhnya ditentukan oleh "kuasa kunci" yaitu Paus atau Uskup atau pemimpin gereja lainnya, sesuai posisinya pada tingkat organisasi gerejanya. Sejumlah tokoh Reformasi memprotes ajaran dan praktik Disiplin GKR, namun ajaran tersebut tidak dibuang sepenuhnya. Misalnya John Calvin, dalam laboratorium gereja Reformasi di Jenewa, ia menyusun ajaran Disiplin dengan tetap memerhatikan warisan ajaran gereja perdana, Bapa-bapa Gereja, dan juga ajaran dan praktik gereja di sekitarnya, sambil tetap melakukan koreksi. ${ }^{3}$

Ajaran Disiplin Calvin diwarisi gereja-gereja Calvinis, termasuk Gereja Toraja. Hal mewariskan ajaran gereja merupakan suatu kewajaran, dan itu umum terjadi sepanjang sejarah gereja. Namun demikian, mewarisi tanpa sikap kritis akan menyebabkan kelemahan ajaran atau ajaran menjadi tidak relevan dengan konteks. Yang lebih utama adalah fakta bahwa hasil tafsir terhadap teks Alkitab yang menjadi dasar ajaran dapat dipengaruhi oleh zaman dan konteks penafsir. Karena itu, jika dilakukan reinterpretasi terhadap teks yang sama pada konteks dan zaman yang berbeda, maka tidak mustahil memunculkan tafsir yang berbeda, sehingga memungkinkan terjadinya perubahan ajaran berdasarkan tafsir terbaru. Berdasar fakta tersebut, tulisan ini hadir sebagai upaya untuk "merekonstruksi” ajaran Disiplin Gereja Toraja. Upaya dalam tulisan ini, secara spesifik dilakukan dengan melakukan reinterpretasi pada teks Matius 18:15-17 sebagai dasar biblis ajaran Disiplin Gereja Toraja.

\section{Ajaran Penggembalaan dan Disiplin Gereja Toraja}

Sesungguhnya ajaran Disiplin Gereja Toraja merupakan bagian integral dari ajaran Penggembalaan. Hal itu diatur dalam Tata Gereja Toraja 2017 Pasal 25, sebagai berikut:

1. Majelis Gereja, dengan kasih sayang menjalankan Penggembalaan mengenai kepercayaan dan kehidupan anggota jemaat berdasarkan perintah Tuhan Yesus Kristus yang adalah Kepala Gereja dan Gembala Yang Baik.

2. Majelis Gereja dan anggota jemaat bertanggung jawab atas pelaksanaan Penggembalaan

\footnotetext{
${ }^{2}$ Jan S Aritonang, Berbagai Aliran Di Dalam Dan Di Sekitar Gereja (Jakarta: BPK Gunung Mulia, 2001): 72

${ }^{3}$ Ibid.
} 
melalui perkunjungan secara terencana dan teratur.

3. Gereja Toraja melaksanakan dua jenis Penggembalaan yaitu Penggembalaan Umum dan Penggembalaan Khusus.

4. Penggembalaan Khusus terhadap anggota jemaat, pejabat khusus gerejawi, dan jemaat dilaksanakan berdasarkan Matius 18:15-17. ${ }^{4}$

Selanjutnya pada bagian Memori Penjelasan Pasal 25, diuraikan tentang perbedaan Penggembalaan Umum dan Penggembalaan Khusus:

1. Penggembalaan Umum merupakan penggembalaan yang dilaksanakan secara terus menerus melalui kebaktian, perkunjungan pastoral, percakapan pastoral, surat penggembalaan, dan bentuk-bentuk penggembalaan lain.

2. Penggembalaan Khusus merupakan penggembalaan yang dilaksanakan kepada anggota jemaat untuk membimbing sampai kepada penyesalan dan pertobatan. Penggembalaan Khusus dilayankan kepada:

a. Anggota jemaat yang kehidupan dan/atau paham pengajarannya bertentangan dengan firman Allah dan Pengakuan Gereja Toraja, merusak diri dan keluarganya, serta menjadi batu sandungan bagi orang lain.

b. Pejabat khusus yang menganut dan mengajarkan ajaran yang bertentangan dengan Firman Allah dan Pengakuan Gereja Toraja, menyalahgunakan jabatannya, melalaikan kewajibannya, menimbulkan kekacauan/ perpecahan dalam jemaat, dan kelakuannya bertentangan dengan Firman Allah dan/atau mengingkari jabatannya sehingga menjadi batu sandungan bagi jemaat dan masyarakat.

c. Jemaat yang mempunyai haluan dan pengajaran yang bertentangan dengan Firman Tuhan atau menyimpang dari Pengakuan Gereja Toraja dan Tata Gereja Toraja serta tidak menaati keputusan-keputusan Sidang Sinode Am. ${ }^{5}$

Cara Pelaksanaan Penggembalaan Khusus Gereja Toraja diatur dalam Petunjuk Teknis Pasal 25, sebagai berikut:

1. Seorang anggota jemaat atau pejabat khusus gerejawi yang telah jatuh ke dalam dosa dinasihati dan ditegur dengan penuh kasih sayang di hadapan empat mata oleh anggota jemaat atau anggota Majelis Gereja yang mengetahuinya. Janganlah hal itu diberitahukan dengan segera kepada Majelis Gereja atau kepada siapapun.

2. Jika pihak yang dinasihati atau ditegur tidak mau mendengar nasihat, mintalah seorang atau dua orang saudara untuk turut sebagai saksi dan memberi nasihat dan teguran

\footnotetext{
${ }^{4}$ BPS Gereja Toraja, Tata Gereja Toraja (Rantepao: BPS Gereja Toraja, 2017): 23-35.

${ }^{5}$ Ibid., 24-25.
} 
kepadanya.

3. Jika nasihat dan teguran ini tidak berhasil, hendaklah diberitahukan kepada Majelis Gereja, supaya Majelis Gereja memberikan nasihat dan teguran lebih lanjut.

4. Jika nasihat dan teguran Majelis Gereja tidak membawa hasil terlebih pula karena dosanya telah diketahui warga jemaat dan orang banyak, maka kepada yang bersangkutan dikenakan disiplin gerejawi, melalui keputusan Sidang Majelis Gereja.

5. Jika proses 1-4 belum dilakukan tetapi dosanya telah diketahui umum, yaitu sudah tersiar kemana-mana dan sudah diketahui orang banyak serta dinyatakan benar sesuai hasil penyelidikan Majelis Gereja, maka kepada yang bersangkutan dikenakan disiplin gerejawi melalui keputusan Sidang Majelis Gereja.

6. Jika seorang pendeta yang jatuh ke dalam dosa dan/atau melakukan hal-hal yang mengakibatkan yang bersangkutan seharusnya menjalani penggembalaan khusus tetapi karena satu dan lain hal tidak ditangani oleh Majelis Gereja dan halnya diketahui Badan Pekerja Sinode Gereja Toraja, maka Badan Pekerja Sinode Gereja Toraja menangani dengan membentuk Tim Penyelidik dan hasil penyelidikan dilaporkan kepada Badan Pekerja Sinode Gereja Toraja. Bila hasil laporan Tim Penyelidik membenarkan hal tersebut, Badan Pekerja Sinode Gereja Toraja melakukan Penggembalaan Khusus kepada yang bersangkutan.

7. Alasan-alasan Penggembalaan Khusus bagi pendeta: a. Mengutarakan atau mengajarkan pengajaran yang bertentangan dengan Firman Tuhan dan Pengakuan Gereja Toraja; b. Melalaikan tugas kewajibannya; c. Meninggalkan jemaat selama 3 (tiga) bulan berturutturut tanpa persetujuan tertulis Badan Pekerja Sinode Gereja Toraja; d. Mempergunakan salah jabatannya; e. Menimbulkan kesangsian atau perpecahan dalam jemaat; f. Pelanggaran terhadap Tata Gereja Toraja; g. Tidak mengindahkan teguran gerejawi tertulis Badan Pekerja Sinode Gereja Toraja 3 (tiga) kali berturut-turut; h. Beralih ke lapangan lain tanpa persetujuan tertulis Badan Pekerja Sinode Gereja Toraja; i. Melakukan dosa-dosa seperti yang dilakukan anggota jemaat, yang menyebabkan dikenakan disiplin gerejawi. ${ }^{6}$

Ajaran Disiplin Gereja Toraja diatur dalam Tata Gereja Toraja Pasal 26. Tata cara Disiplin dilakuan dengan langkah-langkah berikut:

1. Atas perintah Tuhan Yesus Kristus yang adalah Kepala Gereja dan Gembala Yang Baik, Majelis Gereja menasihati atau menegur dengan penuh kasih sayang mengenai

${ }^{6}$ Ibid., 23-24. 
kepercayaan dan kehidupan anggota jemaat.

2. Disiplin gerejawi dilaksanakan dengan maksud: a. Kemuliaan Tuhan; b. Pertobatan dan keselamatan orang-orang yang berdosa; c. Peringatan dan pengajaran bagi seluruh anggota jemaat untuk memelihara kekudusan jemaat Kristus; d. Menyatakan bahwa pintu kerajaan surga tertutup bagi orang yang tetap hidup dalam dosanya tetapi terbuka bagi orang yang bertobat.

3. Disiplin gerejawi dilaksanakan terhadap: a. Anggota Jemaat; b. Penatua; c. Diaken; d. Pendeta. $^{7}$

Jika proses Penggembalaan Khusus kepada orang berdosa tidak berhasil, maka selanjutnya majelis gereja melangkah pada tahap Disiplin. Disiplin diproses dan diumumkan dalam gereja dengan menggunakan Naskah Liturgis Kada Mangullampa Gereja Toraja yaitu:

1. Formulir Hal Melakukan Disiplin Pertama. Pada Disiplin pertama orang yang bersangkutan tidak lagi mendapatkan hak-hak gerejawi antara lain: Tidak diperkenankan turut Perjamuan Kudus, tidak diperkenankan membawa anaknya untuk dibaptis, dan tidak memiliki hak untuk memilih dan dipilih dalam jabatan gerejawi.

2. Formulir Hal Melakukan Disiplin Kedua. Jika Disiplin pertama tidak berhasil menobatkan yang bersangkutan, maka majelis jemaat akan melayangkan Disiplin kedua yang juga diumumkan dalam jemaat. Sanksi Disiplin kedua masih sama dengan Disiplin pertama.

3. Formulir Hal Melakukan Pengucilan. Jika yang bersangkutan tidak bertobat juga pada masa Disiplin pertama, maka majelis jemaat melayangkan keputusan pengucilan dan diumumkan kepada jemaat dengan menggunakan Formulir Hal Melakukan Pengucilan. ${ }^{8}$

Jika memerhatikan ajaran Disiplin Gereja Toraja yang tertuang dalam Tata Gereja Toraja dan Formulir Liturgis Gereja Toraja, tampaknya sudah terjadi modifikasi dasar ajaran dan metode pelaksanaan Disiplin. Gereja Toraja membagi tiga tahap dalam memperlakukan anggota yang berdosa. 1. Penggembalaan Khusus. Penggembalaan Khusus dilakukan menurut proses yang terjadi dalam Matius 18:15-17. Jika pada tahap Penggembalaan tidak berhasil maka dilanjutkan dengan pemberlakuan Disiplin dengan sanksi mencabut beberapa hak gerejawi. Pada tahap Disiplin, majelis gereja tetap

${ }^{7}$ Dalam Tata Gereja Toraja, Disiplin Gerejawi dibagi dalam tiga golongan, yaitu: Disiplin Gerejawi terhadap anggota jemaat, Disiplin Gerejawi terhadap penatua, dan Disiplin Gerejawi terhadap pendeta. Tetapi secara umum, makna dan prosesnya tetap sama (Ibid., 25-27).

${ }^{8}$ BPS Gereja Toraja, Naskah Liturgis Kada Mangullampa Gereja Toraja (Rantepao: BPS Gereja Toraja, 2014): 83-86. 
melakukan Penggembalaan dengan penuh kasih. Jika dalam masa Disiplin pertobatan tidak terjadi, majelis jemaat dengan persetujuan klasis akan bertindak untuk melaksanakan pengucilan. ${ }^{9}$

Hal penting yang dapat disimpulkan dari ajaran dan praktik Disiplin Gereja Toraja, selain fakta bahwa ada yang tidak menerapkan ajaran tersebut, adalah potensi bermuara pada pengucilan (excommunication). Situasi terkucil merupakan situasi di mana sesorang tidak lagi mendapat peluang untuk merasakan persekutuan dalam Kristus bersama jemaat dan merasakan pelayanan dan penggembalaan dari gereja. Situasi demikian berpotensi untuk membuat orang yang terkucil semakin sulit melakukan pertobatan, mendapat tekanan, dan hukuman sosial yang parah. Memperlakukan seseorang dalam keadaan yang demikian merupakan tindakan kekerasan secara psikis, yang perlu dikaji ulang secara teologis.

\section{Warisan John Calvin}

Berdasarkan pemaparan di atas, maka terlihat jelas bahwa rumusan ajaran Disiplin Gereja Toraja merupakan warisan John Calvin, sebab rumusan ajaran dan praktik Disiplin Gereja Toraja tidak jauh berbeda dengan yang tertuang dalam Tata Gereja Belanda 1619 (Tata Gereja Dordrecht), sebagai gereja warisan Calvin. ${ }^{10}$ Sangatlah wajar jika gereja Toraja mewarisi ajaran Calvin, karena Gereja Toraja merupakan buah penginjilan dari lembaga misi dari negeri Belanda yaitu Gereformeerde Zendingsbond (GZB) yang notabene adalah komunitas Kristen atau gereja yang beraliran Calvinis. ${ }^{11}$

Nuansa ajaran Disiplin Gereja Toraja terlihat ketat dan hampir sama dengan ajaran Disiplin Calvin di jemaat Jenewa. Aritonang mengatakan bahwa memang benar, di jemaat Jenewa, Calvin memberlakukan Disiplin dengan sangat ketat. Tetapi ajaran dan praktik tersebut mesti dipahami dalam dua hal mendasar yaitu: Pertama, ajaran Disiplin gereja karya Calvin, dimaksudkan untuk diberlakukan di jemaat Jenewa. Pada saat itu belum terpikir oleh Calvin untuk menyusun Disiplin bagi gereja sedunia. Meskipun nuansa ajaran Disiplin warisan Calvin sangat ketat, ternyata fenomena longgarnya pelaksaan Disiplin, secara khusus pada gereja Calvinis, terjadi dimana-mana. Aritonang mengafirmasi keadaan tersebut dengan pendapat bahwa ciri khas pelaksanaan Disiplin oleh Calvin di jemaat

\footnotetext{
${ }^{9}$ Ibid., 37.

10 Th. Van den End, Enam Belas Dokumen Dasar Calvinisme (Jakarta: BPK Gunung Mulia, 2014): 393-395.

${ }^{11}$ Th. Van den End, Sumber-Sumber Zending Tentang Sejarah Gereja Toraja 1901-1961 (Jakarta: BPK Gunung Mulia, 1994): 3.
} 
Jenewa tidak berlaku sama ketatnya dengan pelaksanaan Disiplin dalam gereja-gereja Calvinis. Oleh karena itu, tidak dapat disimpulkan bahwa semua gereja Calvinis memberlakukan ajaran Disiplin secara ketat. ${ }^{12}$

Kedua, Calvin bukanlah orang yang pertama kali berfikir dan bertindak dalam perkara Disiplin. Salah satu contohnya adalah Augustinus, sebagai wakil gereja lama yang memberi perhatian terhadap hal Disiplin. Pandangan serta cara-cara Disiplin Augustinus berpengaruh besar bagi Calvin. Dalam penyusunan peraturan Disiplin bagi jemaat Jenewa, Calvin sangat memerhatikan warisan zaman gereja perdana dan sekaligus mengoreksi pandangan dan praktik gereja-gereja di sekitarnya. Dalam hal ini, bukan hanya GKR saja yang dikecam dan ditolaknya, melainkan juga kaum Anabaptis. Kaum Anabaptis adalah kaum yang bercita-cita mewujudkan gereja yang terdiri dari orang-orang suci dan kesucian itu terletak pada warganya. ${ }^{13}$ Calvin sependapat dengan Martin Luther, yang menekankan bahwa kesucian gereja bukan terletak pada manusianya, melainkan pada Allah yang menetapkan kehadiran gereja itu dan yang mengaruniakan pengampunan serta keselamatan melalui gereja-Nya. ${ }^{14}$ Jadi dapat disimpulkan bahwa ajaran Disiplin, sejak semulanya berkaitan dengan kesucian hidup.

Bagi Calvin, gereja adalah suci karena karena Allah adalah suci dan memercayakan kepada gereja-Nya perkara-perkara suci, yakni Firman dan sakramen. Namun kesucian lahiriah seperti yang dikejar oleh kaum Anabaptis, tidak mungkin dicapai manusia di dalam kehidupan masa kini, kendati manusia harus terus-menerus mengupayakan dalam sepanjang hidupnya, sebagai suatu proses yang tidak pernah selesai. Kesucian yang sempurna hanya terwujud pada akhir zaman, ketika Allah sendiri mengaruniakannya kepada gereja-Nya yaitu orang-orang yang beriman kepada-Nya. Karena itu, bagi Calvin, menuntut kesucian lahiriah pada masa kini berarti menyangkal kenyataan bahwa gereja, di samping sebagai persekutuan orang-orang kudus, juga terdiri dari orang-orang berdosa yang setiap hari berjuang melawan dosa, namun juga setiap hari membutuhkan pengampunan agar layak menghadap Allah. ${ }^{15}$

Menurut Calvin, ada tiga tujuan yang ingin dicapai dari Disiplin gerejawi dalam bentuk teguran dan pengucilan bagi orang berdosa. Pertama, supaya mereka yang menempuh hidup kejahatan dan kekejian tidak digolongkan sebagai orang Kristen. Penggolongan orang berdosa dan yang tidak mau bertobat sebagai orang Kristen akan

\footnotetext{
${ }^{12}$ Aritonang, Berbagai Aliran Di Dalam Dan Di Sekitar Gereja.

${ }^{13}$ Ibid., 72.

${ }^{14}$ Ibid., $72-73$.

15 Ibid., 73.
} 
menyebabkan penghinaan terhadap Allah. Seakan-akan, gereja-Nya yang kudus (Ef. 5:25) menjadi sarang orang yang jahat dan bejat. Kedua, supaya orang-orang baik tidak dirusak karena terus-menerus bergaul dengan orang-orang jahat, sebagaimana yang biasanya terjadi. Calvin melihat bahwa manusia mempunyai kecenderungan untuk terbawa arus oleh orang yang sesat, untuk ikut tersesat. Ketiga, supaya mereka sendiri, karena malu, mulai menyesali kejahatan mereka. Bagi orang berdosa, ada gunanya bila kejahatan mereka mendapat hukuman, supaya mereka terbangun oleh rasa pedihnya cambukan-cambukan Disiplin dan pengucilan. Kalau dibiarkan saja, mereka akan semakin menjadi-jadi dalam perbuatan dosanya. ${ }^{16}$

\section{Kajian Biblis tentang Disiplin Gereja}

Matius 18:15-17 merupakan dasar Alkitab yang dipakai oleh Gereja Toraja dalam menerapkan penggembalaan dan Disiplin gereja. Jika memerhatikan proses Disiplin dalam gereja Calvinis, maka dapat disimpulkan bahwa secara umum gereja-gereja Calvin menggunakan dasar teks Matius 8:15-17. David L. Burggraff sepakat dengan hal itu dan mengatakan bahwa Matius 18:15-17 merupakan teks yang paling umum dijadikan dasar pemberlakuan Disiplin dalam gereja, namun seharusnya, teks itu ditafsir dalam konteks keseluruhan Injil Matius. ${ }^{17}$ Pandangan tersebut, senada dengan pendapat Ramshaw bahwa kita mesti memikirkan ulang pemaknaan teks Matius 18:15-18, supaya kita tidak jatuh ke dalam penafsiran yang keliru. ${ }^{18}$

Beberapa penafsir berpandangan bahwa penulis Injil Matius mengumpulkan materi Injil Matius tanpa memberikan sebuah kesatuan interpretasi. Salah satu contohnya adalah Matius 18 yang memperlihatkan makna yang kontradiktif, misalnya ayat 15-20 yang dianggap mengusung makna pengampunan yang terbatas melalui pengucilan, sementara ayat 21-35 mengusung makna pengampunan yang tidak terbatas. Hickling berpandangan bahwa kontradiksi makan tersebut merupakan akibat dari penulis yang tidak melakukan editing terhadap materi-materi Injil sehingga teks tidak saling mendukung satu dengan yang lainnya. ${ }^{19}$

\footnotetext{
${ }^{16}$ John Calvin, Calvin: Institutes of the Christian Religion (Philadelphia: The Westminister Press, 1536): 1232-1233.

${ }^{17}$ David L. Burggraff, "Principles of Discipline in Matthew 18:15-17, Part I: A Contextual Study," Calvary Baptist Theological Journal (1988): 4. 402.

${ }^{18}$ Elaine J Ramshaw, "Power and Forgiveness in Matthew 18," Word \& World XVIII, no. 4 (1998):

${ }^{19}$ C. J. A Hickling, "Conflicting Motives in the Redaction of Matthew: Some Considerations on the Sermon on the Mount and Matthew 18:15-20," Studia Evangelica 7 (1982): 259.
} 
Kebanyakan penafsir, sekalipun mengakui adanya ketegangan dalam pasal 18, namun tetap mencoba menghubungkan setiap bagian teks untuk memberikan arti secara komprehensif. Salah satu cara penyelesaian ketegangan dalam Matius 18 adalah dengan memahami bahwa pembahasan tentang orang yang berdosa dalam ayat 15-20, dibingkai oleh perumpamaan-perumpamaan dan narasi yang menekankan anugerah, pengampunan, perintah untuk mencari yang terhilang, dan persaudaraan. ${ }^{20}$ John R. Donahue misalnya, berpandangan bahwa perumpamaan tentang domba yang hilang (Mrk. 18:12-14) merupakan pendahuluan yang kelihatannya adalah sebuah kritik tajam terhadap model pemberlakuan aturan komunitas yang cenderung terarah pada anggota terlemah. ${ }^{21}$

Mathew berpendapat bahwa penempatan Matius 18:15-18 di antara perumpamaan domba yang hilang (Mat. 18:12-18) dan jaminan Allah bagi permohonan orang yang bersepakat (Mat. 18:19) memperjelas bahwa setiap usaha harus dibuat oleh orang yang berdamai. ${ }^{22}$ Sementara itu, Daniel Patte mengatakan bahwa motivasi menghadapi orang yang berdosa terletak pada ayat $15 \mathrm{~b}$ "jika ia mendengarkan nasihatmu, engkau telah mendapatkannya kembali”. Pentingnya memperoleh saudara kembali, digarisbawahi dalam ayat 18-20 yang menekankan bahwa dua orang yang bersepakat menjadikan doa mereka dikabulkan, dan dua atau tiga orang yang berkumpul, dijaminkan bahwa Yesus akan hadir ditengah-tengah mereka. ${ }^{23}$

Davies dan Allison melihat bahwa ayat 1-14 merupakan setting pentas bagi diskusi perdamaian dengan mengangkat kebajikan yang penting bagi komunitas Kristen yaitu Kerendahan hati (ayt. 3-4), kebaikan khusus bagi anak-anak (ayt. 5), menahan diri untuk menyerang orang lain, khususnya orang lemah atau orang yang terpinggirkan (ayt. 6-7), pengendalian diri yang serius (ayt. 8-9), dan kasih kepada semua orang percaya, termasuk anak-anak (ayt. 10-14). Seluruh tindakan tersebut akan mengoreksi keinginan untuk menghakimi yang lain dan memakai pendekatan koreksi persaudaraan (ayt. 15-20). ${ }^{24}$

Menurut Ramshaw, semua argumentasi pada ayat 15-18 harus dipahami dalam hubungannya dengan teks sebelum dan sesudahnya. Teks sebelum dan sesudah ayat 15-18 merupakan bingkai bagi prosedur untuk memperlakukan saudara-saudara yang berdosa. Konfrontasi di dalam teks dimotivasi oleh keinginan yang kuat untuk melakukan

\footnotetext{
${ }^{20}$ John R Donahue, The Gospel in Parable (Philadelphia: Fortress, 1988): 73.

21 Ibid.

${ }^{22}$ Parackel Mathew, "Authority and Discipline: Matt. 16.17-19 and 18.15-18 and the Exercise of Authority and Discipline in the Matthean Community," Communio Viatorum 28 (1985): 123-124.

${ }^{23}$ Daniel Patte, The Gospel According to Matthew (Philadelphia: Fortress, 1987): 253-255.

${ }^{24}$ W. D. Davies and Dale C. Allison, A Critical and Exegetical Commentary on the Gospel According to Saint Matthew, II. (Edinburgh: T\&T Clark, 1991): 777.
} 
rekonsiliasi, pengendalian agar tidak menjadi batu sandungan, dan kerendahan hati. ${ }^{25}$ Pandangan tersebut didukung oleh Davies dan Allison yang berpandangan bahwa ajaran pengampunan "tujuh puluh kali tujuh" (Mat. 18:22b) ${ }^{26}$ ditempatkan setelah ayat 15-22 untuk menanamkan sikap pengampunan dalam komunitas. ${ }^{27}$

Dalam pengamatan Ramshaw, banyak penafsir yang menyadari bahaya terhadap pengambilan perikop Matius 18:15-18 di luar dari konteksnya sebagai legitimasi Disiplin gereja, dan juga menyadari bahwa bahaya yang sama terjadi pada ayat 21-22 sebagai teks untuk menjadi dasar pengampunan tidak bersyarat dan tidak berbatas. Namun pada umumnya para penafsir cenderung berpandangan bahwa pengampunan yang tidak berbatas adalah cita-cita dari kasih dan melihat bahwa pemberlakuan pengampunan tidak berbatas tidak akan mendatangkan kerusakan dalam komunitas. ${ }^{28}$

Sejumlah bapa gereja berpandangan bahwa Matius adalah penulis Injil Matius. Mereka antara lain Clement dari Roma, Polycarpus, Yustinus Martir, Clement dari Alexandria, Tertulianus, dan Origenes. ${ }^{29}$ Teks Injil Matius sendiri juga memuat banyak catatan yang mendukung argumentasi bahwa Matius adalah penulis Injil pertama tersebut. Catatan Injil yang merujuk bahwa Matius bekerja sebagai pemungut cukai antara lain Matius 9:9-13; Matius 10:3; Markus 2:13-17; dan Lukas 5:27-32. ${ }^{30}$

Menurut catatan Injil Matius, pekerjaan Matius adalah sebagai pemungut cukai. Oleh karena pekerjaan tersebut maka Matius tertarik untuk mencatat kisah tentang uang, seperti dalam narasi: Pajak dua dirham (Mat. 17:24), empat mata uang dirham (Mat. 17:24), sepuluh ribu talenta (Mat. 18:24), dan perumpamaan tentang talenta (Mat. 25:1430). Fakta yang semakin mengukuhkan profesi Matius sebagai pemungut cukai adalah pembandingan Injil Matius dengan ketiga Injil yang lain, yang memperlihatkan bahwa Injil Matius lebih banyak mencatat topik-topik tentang uang. ${ }^{31}$

Injil Matius memiliki karakter ke-Yahudi-an. Hal itu dibuktikan dengan beberapa hal: Pertama, menurut Robertson, penulis Injil Matius memiliki naluri paralelisme dan

${ }^{25}$ Ramshaw, "Power and Forgiveness in Matthew 18."

${ }^{26}$ Dalam Alkitab terjemahan baru LAI, kalimat "tujuh puluh kali" diterjemahkan "tujuh puluh kali tujuh kali” (Mat. 18: 22b).

${ }^{27}$ Davies and Allison, A Critical and Exegetical Commentary on the Gospel According to Saint Matthew.

${ }^{28}$ Ramshaw, "Power and Forgiveness in Matthew 18."

${ }^{29}$ Norman L. Geisler and William E. Nix, A General Introduction to the Bible (Chicago: Moody Press, 1968): 193.

${ }^{30}$ Menurut Injil Lukas dan Markus, murid pemungut cukai (Matius) diberi nama Lewi. Markus memberi keterangan lebih bahwa Matius adalah si pemungut cukai, anak dari Alfeus (Burggraff, "Principles of Discipline in Matthew 18:15-17, Part I: A Contextual Study.”)

${ }^{31}$ Ibid., 5. 
elaborasi Ibrani. Pikiran dan gaya penulisan Injil Matius juga berkarakter Ibrani. Kosakata yang digunakan adalah kosakata Ibrani seperti "Kerajaan Surga" (Mat. 5:3, 20; 6:33; 10:57; 13:44-45). Istilah tersebut tidak dipakai dalam ketiga Injil yang lain. Istilah yang digunakan oleh Injil yang lain adalah Kerajaan Allah (Luk. 6:20; 9:2; 10:9,11; 17:21; Mrk. $1: 15 ; 9: 47 ; 12: 34$; Yohanes 3:3,5). ${ }^{32}$

Topik-topik utama yang dibahas oleh Injil Matius adalah topik yang berhubungan dengan Yahudi seperti misalnya Hukum, pengotoran upacara, Sabat, kerajaan, Yerusalem, Mesias, pemenuhan nubuat dalam Perjanjian Lama. Indikasi lain yang memperlihatkan karakter ke-Yahudi-an Injil Matius adalah fakta bahwa ada banyak kutipan dari Perjanjian Lama yang muncul dalam Injil Matius. Ada sekitar 120 referensi dari Perjanjian Lama dan gaya menulis demikian memberi arti bahwa Injil Matius ditujukan kepada pembaca Yahudi. Tanda lain yang menunjukkan karakter Yahudi dalam Injil Matius adalah pemaparan tentang sejumlah kebiasaan Yahudi yang memberi kesan bahwa pembacanya memahami kebiasaan tersebut. ${ }^{33}$ Bukti yang lebih kongkrit adalah kesaksian bapa gereja, Irenius yang mengatakan bahwa:

Matthew issued a written Gospel among the Hebrews;' and The Gospel of St. Matthew was written for the Jews:' Origen says, "St. Matthew wrote for the Hebrew. "Eusebius says: "Matthew ... delivered his gospel to his countrymen". ${ }^{34}$

Indikasi-indikasi tersebut memperjelas dan mengukuhkan bahwa Injil Matius ditujukan kepada pembaca Yahudi. Matius memiliki dua tujuan dalam menulis Injilnya: Pertama, untuk membuktikan bahwa Yesus adalah Mesias. Kedua, untuk menjelaskan program Kerajaan Allah kepada pembacanya. Matius menggunakan referensi Perjanjian Lama untuk meyakinkan pembacanya yaitu orang Yahudi, bahwa Yesus adalah pemenuhan nubuat dalam Perjanjian Lama, sang Mesias yang dijanjikan. Jadi, Matius menulis Injil Matius untuk mejelaskan kepada orang Yahudi bahwa program Kerajaan Allah berhubungan dengan Yesus, sang Mesias. Matius mencatat bahwa konsep kerajaan dan Yesus sebagai rajanya telah ditolak oleh orang Yahudi (Mat. 21:28-22:10; 11:16-24). ${ }^{35}$

Matius, selanjutnya menunjukkan Kerajaan yang tertunda itu dan Kerajaan tersebut akan dinyatakan pada kedatangan Kristus yang kedua (Mat. 19:28; 20:20-23; 23:39; 24:2931; 25:31-46). Dalam proses itu, Allah menyatakan program yang tersembunyi yaitu gereja

\footnotetext{
${ }^{32}$ Stanley D Toussaint, Behold the King: A Study of Matthew (Portland: Multnomah Press, 1980): 16.

${ }^{33}$ Burggraff, "Principles of Discipline in Matthew 18:15-17, Part I: A Contextual Study."

${ }^{34}$ W. Graham Scroggie, A Guide to the Gospels (Old Tappan, NJ: Revell, 1975): 284.

${ }^{35}$ Burggraff, "Principles of Discipline in Matthew 18:15-17, Part I: A Contextual Study.", 6.
} 
yang diramalkan Yesus dalam Matius 16:28. Matius memperlihatkan karakter universal dari program gereja (Mat. 28:19,20) yang menyatakan bahwa orang-orang bukan Yahudi/ bangsa-bangsa lain - kafir - juga dirangkul di dalam program Allah. Klaim bahwa tujuan Matius adalah hanya membuktikan Yesus sebagai Mesias adalah keliru, sebab Matius juga memperlihatkan bahwa bangsa-bangsa lain dihubungkan dengan program Kerajaan Allah. $^{36}$

\section{Penggembalaan Khusus}

Jika memerhatikan kajian di atas, maka sangat disayangkan bahwa banyak gereja telah menjadikan perikop Matius 18:15-17 sebagai dasar biblis yang kuat untuk melaksanakan Disiplin dan bahkan pengucilan tetapi mengabaikan prinsip yang lebih utama dari narasi Matius 18 yaitu kerendahan hati, anugerah, perhatian kepada yang lemah, perasaan, dan tindakan yang saling membutuhkan. Jika tidak mempertimbangkan argumentasi-argumentasi tersebut, maka mungkin kita akan mempertahankan prosedur Matius 15-16 dan mengabaikan teks-teks di sekitarnya. Gereja-gereja seharusnya berhatihati dalam menentukan teks Alkitab untuk dijadikan dasar menyingkirkan orang yang berdosa atau orang yang menyebabkan masalah dalam jemaat.

Kajian tersebut memperlihatkan kesalahan gereja dalam memahami Matius 18:1617 dan penulis ingin mengajak untuk memerhatikan secara khusus teks Matius 18:17 yang menceritakan Pengajaran Yesus bahwa jika seseorang tidak mau mendengarkan nasihat jemaat, maka orang tersebut akan dipandang sebagai "orang yang tidak mengenal Allah" atau "seorang pemungut cukai". Dua kata tersebut disimpulkan oleh gereja-gereja sebagai posisi untuk mengucilkan orang berdosa dari komunitas atau ekskomunikasi/ pengucilan. Pertanyaan penting yang mesti diajukan adalah "jika penulis Injil Matius adalah seorang pemungut cukai - atau mantan pemungut cukai-yang diterima Yesus dalam keadaan yang demikian, maka mungkinkah Matius bermaksud menekankan ayat 17 sebagai ajaran untuk mengeluarkan orang berdosa dari komunitas? Mungkinkah Matius bermaksud untuk menyingkirkan orang-orang non-Yahudi (bangsa-bangsa lain)?

Sekalipun Matius mengalamatkan Injilnya bagi orang Yahudi, namun Matius juga menekankan bahwa program Kerajaan Allah menjangkau non-Yahudi (bangsa-bangsa lain). Matius pasal 18 menekankan prinsip cinta kasih, pengampunan tanpa batas, kerendahan hati, anugerah, perhatian kepada yang lemah, dan hubungan yang saling

${ }^{36}$ Toussaint, Behold the King: A Study of Matthew. 
membutuhkan dalam komunitas. Dengan demikian, tidak ada sikap atau tindakan yang mengarah pada pengucilan orang berdosa.

Jadi, sikap apa yang tepat bagi orang berdosa? Apakah dosa ditoleransi? Matius pasal 18 menjadi jawaban terhadap masalah itu, bahwa dosa tidak ditoleransi tetapi dipandang sebagai keadaan seseorang yang perlu diberi perhatian khusus. Perhatian khusus yang dimaksud adalah Penggembalaan Khusus dan perhatian khusus secara intens bagi yang berdosa dan tersesat (Mat. 18;12-14). Penggembalaan Khusus memberi perhatian khusus, waktu, dan tenaga yang lebih untuk mengajar, untuk membuktikan bahwa Allah mengasihi orang tersebut dan Allah ingin ia tidak tesesat lagi.

Penggembalaan Khusus sebenarnya bukan hal yang baru bagi Gereja Toraja. Penggembalaan Khusus dalam Gereja Toraja merupakan langkah awal untuk membawa jemaat menyesali dosanya. Penggembalaan adalah mutlak dilakukan bagi jemaat dan seharusnya tidak pernah sampai pada Disiplin atau bahkan pengucilan. Penggembalaan Khusus harus bersifat pengampunan yang tidak terbatas dan tidak terhingga. Lagipula tidak ada ukuran standar untuk menilai seseorang layak untuk diDisiplinkan atau dikucilkan. Dosa pun bervariasi, ada yang kelihatan dan ada yang tidak kelihatan. Jika demikian adanya, maka dapatkah kita mengambil kesimpulan untuk menilai dan memutuskan perlakuan Disiplin atau pengucilan bagi seseorang?

Matius 7:1-5 menjadi peringatan bagi setiap orang percaya untuk tidak menghakimi pihak lain. Bahkan perikop ini menekankan bahwa yang terjadi seharusnya adalah introspeksi diri, yaitu memerhatikan bahwa alih-alih melihat selumbar di mata orang lain, jangan-jangan justru ada balok di mata sendiri. Matius 13:24-26 yaitu perumpamaan tentang lalang di antara gandum, juga menjadi narasi pengajaran Yesus Kristus tentang penghakiman. Melalui perumpamaan tersebut, Yesus mengajarkan bahwa urusan penghakiman adalah urusan Tuhan pada akhir zaman. Keadaan bahwa benih yang baik dan benih yang buruk tumbuh bersama merupakan keadaan yang pasti akan terjadi dalam dunia (Mat. 36: 36-43). Kristus tidak ingin memanjakan dan melindungi umat-Nya dengan cara membersihkan semua yang berbau dosa dalam komunitasnya. Kristus ingin agar setiap pengikut-Nya tangguh dalam mempertahankan iman, sekalipun hidup berziarah dalam dunia yang penuh dengan orang-orang yang jahat dan berdosa. 


\section{Kesimpulan}

Sudah saatnya gereja-gereja yang lahir dari warisan gereja klasik yang mewarisi doktrin klasik seperti gereja Calvinis dan gereja Lutheran, untuk melakukan reinterpretasi terhadap teks Alkitab yang dijadikan dasar ajaran atau doktrin. Juga penting untuk disadari oleh gereja-gereja, bahwa doktrin yang dibangun dalam konteks gereja-gereja klasik dipengaruhi oleh konteks pada zaman itu. Maka, tidak tepat dan tidak bijak untuk mengambil secara utuh atau mengambil tanpa sikap kritis dan melakukan interpretasi ulang terhadap warisan teologi dan ajaran gereja-gereja sebelumnya.

Fenomena yang sama terlihat di Gereja Toraja. Fakta yang muncul yaitu ajaran Disiplin hanya sebagai ajaran "hitam di atas putih" dan tidak dihidupi atau sungguhsungguh menjadi ajaran yang dihidupi tetapi tidak relevan dengan konteks jemaat. Hal yang paling utama adalah Gereja Toraja semestinya melakukan penafsiran secara bertanggungjawab terhadap teks Matius 18:15-17, sebelum teks tersebut dijadikan dasar ajaran gereja - dalam hal ini ajaran Disiplin dan pengucilan.

Sikap dan tindakan yang paling tepat bagi orang berdosa berdasarkan teks Matius 18 adalah memberikan perhatian khusus secara intensif yaitu penggembalaan khusus. Penggembalaan khusus merupakan cerminan kasih Allah kepada dunia yang tidak terbatas dan tidak terhingga. Pengampunan perlu diberikan secara terus-menerus bagi sesama, sebab kita sadar bahwa manusia adalah mahluk yang terbatas dan pada dirinya tidak ada potensi kesempurnaan. Kesempurnaan dan kesucian hidup manusia, sebagaimana menurut Calvin hanya akan terwujud pada zaman akhir.

\section{Kepustakaan}

Aritonang, Jan S. Berbagai Aliran Di Dalam Dan Di Sekitar Gereja. Jakarta: BPK Gunung Mulia, 2001.

Burggraff, David L. "Principles of Discipline in Matthew 18:15-17, Part I: A Contextual Study." Calvary Baptist Theological Journal (1988): 1-23.

Calvin, John. Calvin: Institutes of the Christian Religion. Philadelphia: The Westminister Press, 1536.

Davies, W. D., and Dale C. Allison. A Critical and Exegetical Commentary on the Gospel According to Saint Matthew. II. Edinburgh: T\&T Clark, 1991.

Donahue, John R. The Gospel in Parable. Philadelphia: Fortress, 1988.

End, Th. Van den. Enam Belas Dokumen Dasar Calvinisme. Jakarta: BPK Gunung Mulia, 2014. 
- Sumber-Sumber Zending Tentang Sejarah Gereja Toraja 1901-1961. Jakarta: BPK Gunung Mulia, 1994.

Geisler, Norman L., and William E. Nix. A General Introduction to the Bible. Chicago: Moody Press, 1968.

Hickling, C. J. A. "Conflicting Motives in the Redaction of Matthew: Some Considerations on the Sermon on the Mount and Matthew 18:15-20." Studia Evangelica 7 (1982).

Mathew, Parackel. "Authority and Discipline: Matt. 16.17-19 and 18.15-18 and the Exercise of Authority and Discipline in the Matthean Community." Communio Viatorum 28 (1985).

Milavec, Aaron. The Didache: Faith, Hope, \& Life of the Erliest Christian Communities, 50-70 C.E. New York: The Newman Press, 2003.

Patte, Daniel. The Gospel According to Matthew. Philadelphia: Fortress, 1987.

Ramshaw, Elaine J. "Power and Forgiveness in Matthew 18." Word \& World XVIII, no. 4 (1998): 397-404.

Scroggie, W. Graham. A Guide to the Gospels. Old Tappan, NJ: Revell, 1975.

Toraja, BPS Gereja. Naskah Liturgis Kada Mangullampa Gereja Toraja. Rantepao: BPS Gereja Toraja, 2014.

—. Tata Gereja Toraja. Rantepao: BPS Gereja Toraja, 2017.

Toussaint, Stanley D. Behold the King: A Study of Matthew. Portland: Multnomah Press, 1980. 